\title{
SISTEM PENUNJANG KEPUTUSAN CALON DESA PENERIMA AIR BERSIH DI KECAMATAN SUMBERLAWANG SRAGEN MENGGUNAKAN METODE SIMPLE ADDITIVE WEIGHTING
}

\author{
Novianto Tri Sasongko ${ }^{1)}$; Sri Tomo ${ }^{2)}$; Sri Hariyati Fitriasih ${ }^{3)}$ \\ ${ }^{1,2)}$ Program Studi Teknik Informatika, STMIK Sinar Nusantara \\ ${ }^{3)}$ Program Studi Manajemen Informatika, STMIK Sinar Nusantara \\ 1)sasongkonovianto@gmail.com; ${ }^{2)}$ schzrie@gmail.com; ${ }^{3)}$ fitri@sinus.ac.id
}

\begin{abstract}
The purpose of this study is to make a decision support system that makes it easier for Sumberlawang District in terms of determining candidate villages receiving clean water in the area. So that the determination of distribution becomes faster and precise. The system built by the author uses a decision support method that is Simple Additive Weighting (SAW). In performing attribute selection, the author uses 4 criteria in determining the selection of water recipient village candidates. The programming language of the author uses the programming language HyperText Preprocessor (PHP). The software that supports in making applications that Macromedia Dreamweaver, Mysql, and Adobe Photoshop. The result of the use of SAW method is the creation of a Decision Supporting System Support System for Water Recipient Village in Sumberlawang Sragen Using Simple Additive Weighting Method which is very helpful to Sumberlawang Sub-District in Determination of Potential of Recipient of Clean Water.

Keywords: Decision Support System, SAW Method, Water Distributor.
\end{abstract}

\section{PENDAHULUAN}

Pemerintah Kecamatan Sumberlawang sudah melakukan usaha pengadaan air bersih dari PDAM atau pengambilan air dari lokasi lain. Oleh karena itu usaha yang dilakukan hanya untuk Menentukan calon desa peneima air bersih dengan melakukan penyaringan berdasarkan kriteria masyarakat pertama berdasarkan kondisi lingkungan, yang kedua berdasar ekonomi masyarakat.

Untuk sistem yang dijalankan saat ini dilakukan belum secara maksimal karena masih dengan sistem pendataan dari ekonomi saja dan kondisi lokasi penduduk yang belum mendapat ketersediaan air bersih sering dilalaikan. Tentunya hal ini mengakibatkan tidak maksimalnya distribusi dan kurang meratanya pendistribusian.

Terdapat suatu solusi untuk mengatasi masalah tersebut yaitu dengan membangun Sistem Penunjang Keputusan Calon Desa Penerima Air Bersih Menggunakan Metode Simple Additive Weighting. Diharapkan dengan adanya sistem penunjang keputusan ini maka dapat mengatasi permasalahan dalam penentuan calon desa penerima air bersih.

\section{TINJAUAN PUSTAKA}

Beberapa teori yang digunakan dalam proses penelitian diantaranya teori tentang sistem pendukung keputusan, Hyper text preprocessor (PHP), dan teori tentang Simple Additive Weighted (SAW).

\subsection{Sistem Pendukung Keputusan}

Sistem pendukung keputusan dapat digambarkan sebagai sistem yang berkemampuan mendukung analisis ad hoc data, dan pemodelan keputusan, berorientasi keputusan, orientasi perencanaan masa depan, dan digunakan pada saat-saat yang tidak biasa[1].

\subsection{Simple Additive Weighted}

Simple Additive Weighted(SAW) adalah metode terkenal yang diterapkan dalam lingkungan fuzzy[2]. Penerapan pengambilan keputusan kuantitatif guna membandingkan bahan bakar fosil dengan energi nuklir untuk pembangkit tenaga listrik,dengan metode DEA dan SAW[3]. Multi criteria decision menyediakan alat yang handal dalam masalah sorting. Teknik sederhana yang dapat digunakan untuk evaluasi antara lain metode SAW[4]. Dalam penilaian risiko dalam industri farmasi di Iran yang mempertimbangkan prioritas proses, bahaya dan probabilitas risiko, metode SAW digunakan untuk evaluasi resiko[5]. Ditemukan metode untuk menurunkan pembobotan yang menghasilkan peringkat yang sama sebagaimana yang 
diberikan oleh metode Multiple Criteria Decision Analysis[6].

Metode SAW sering juga dikenal istilah metode penjumlahan terbobot. Konsep dasar metode SAW adalah mencari penjumlahan terbobot dari rating kinerja pada setiap alternatif pada semua atribut. Metode SAW membutuhkan proses normalisasi matriks keputusan (X) ke suatu skala yang dapat diperbandingkan dengan semua rating alternatif yang ada[7]. Metode agregasi umum Multi-attribute utility theory (MAUT) untuk keputusan kelompok adalah metode SAW, yang tidak mempertimbangkan tingkat preferensial yang berbeda dan peringkat preferensial untuk penilaian pengambil keputusan individu dari alternatif dalam kelompok keputusan[8]. Teori prospek diusulkan untuk menyelesaikan masalah Multiple Attribute Decision Making (MADM) dengan mempertimbangkan tingkat aspirasi atribut[9].

Menurut Kusumadewi[10], Langkahlangkah penelitian dalam menggunakan metode SAW, adalah :

1. Menentukan kriteria-kriteria yang akan dijadikan acuan dalam pengambilan keputusan, yaitu $\mathrm{C}_{\mathrm{i}}$.

2. Menentukan rating kecocokan setiap alternative pada setiap kriteria.

3. Membuat matriks keputusan berdasarkan kriteria $\left(\mathrm{C}_{\mathrm{i}}\right)$, kemudian melakukan normalisasi matriks berdasarkan persamaan yang disesuaikan dengan jenis atribut (atribut keuntungan maupun atribut biaya) sehingga diperoleh matriks ternormalisasi $\mathrm{R}$.

\section{METODE PENELITIAN}

Dalam metode penelitian penulis mencari suatu data dengan teknik / metode pengumpulan data, adapun jenis data yang diperlukan yaitu.

\subsection{Jenis Data}

a) Data primer

Data Primer adalah data utama yang diperoleh langsung dari Kecamatan Sumberlawang. Data tersebut merupakan data utama yang akan dikelola dalam proses penentuan ditribusi air bersih Adapun data utama yang digunakan dalam penelitian ini adalah sebagai berikut.

a. Data jumlah rumah yang ada di wilayah tersebut

b. Data medan atau struktur tanah di wilayah tersebut c. Data jarak rumah dari penampungan air

d. Data penghasilan warga di wilayah tersebut

e. Data warga yang menjadi calon atau calon tempat distribusi air bersih

b) Data Sekunder

Data Sekunder adalah data yang diperoleh dari buku yang mendukung penelitian. Data diperoleh dari media pustaka tentang teori-teori tentang objek-objek yang digunakan dalam pembuatan aplikasi tersebut. sehingga aplikasi ini dapat dijadikan suatu aplikasi dengan landasan teori yang benar.

\subsection{Metode Pengumpulan data}

Adapun metode pengumpulan data yang dilakukan oleh Penulis antara lain.

a) Observasi

Penulis melakukan kunjungan langsung ke Kecamatan Sumberlawang serta menyakan langsung kepada Bapak Supardi selaku ahli di bidang air bersih dan sekaligus kepala pendistribusian air bersih di kecamatan sumberlawang. Hal tersebut dilakukan dengan tujuan agar penulis dapat mengetahui secara langsung proses penentuan tempat distribusi air bersih dengan metode yang sudah berjalan. Selanjutnya penulis akan menyusun langkah-langkah yang sistematis dalam membuat sistem penentuan calon penerima insentif menggunakan metode SAW (Simple Additive Weighted).

b) Wawancara

Setelah dilakukan wawancara dengan pihak Kecamatan Sumberlawang, diketahui bahwa penggunaan metode perhitungan per poin dari setiap calon distributor, terdapat kelemahan. Kelemahan tersebut adalah dengan metode tersebut tidak dapat menghitung kriteria yang lain seperti medan dan jarak rumah. Selain itu dengan metode yang sudah ada. Sistem tidak dapat membuat pembobotan setiap kriteria. Karena setiap kriteria menurut pihak Kecamatan ada kriteria yang diprioritaskan.

c) Studi Pustaka

Penulis mencari referensi pada bukubuku yang berkaitan dengan permasalahan tersebut.

\subsection{Metode Analisa Sistem}

Penulis dalam hal ini juga menerapkan metode penelitian dengan analisa permasalahan, menggunakan teori Simple Additive Weighthed.

Sebuah analisa yang berbasis Simple Additive Weighthed (SAW) karena dengan 
metode Simple Additive Weighthed memungkinkan menyelesaikan analisa dengan multi kriteria. Adapun kriteria untuk memilih calon distributor air bersih adalah sebagai berikut :
1. Jumlah Rumah
2. Medan
3. Jarak Distribusi
4. Penghasilan

\section{HASIL DAN PEMBAHASAN}

\subsection{Perhitungan Bobot}

Untuk mengetahui besar prioritas setiap kriteria maka penulis harus menghitung bobot prioritas tiap kriteria. Adapun perhitungan bobot prioritas adalah sebagai berikut.

\section{Membuat Normalisasi}

Formula untuk melalukan normalisasi tersebut adalah sebagai berikut :

$r_{i j}=\left\{\begin{array}{l}\frac{x_{i j}}{{ }^{M a x}{ }_{i} x_{i j}} \\ \frac{{ }^{M i n}{ }_{i j} x_{i j}}{x_{i j}}\end{array}\right.$.

Keterangan :

$\mathrm{r}_{\mathrm{ij}} \quad=$ nilai rating kinerja ternormalisasi

$\mathrm{x}_{\mathrm{ij}} \quad=$ nilai atribut yang dimiliki dari setiap kriteria

$\operatorname{Max} x_{i j}=$ nilai terbesar dari setiap kriteria

Min $x_{i j}=$ nilai terkecil dari setiap kriteria

a) Kriteria Jumlah Rumah

Kriteria Jumlah rumah menurut pihak Kecamatan Sumberlawang merupakan kriteria yang paling bagus apabila mempunyai nilai yang maksimal (benefit). Dimana diketahui dari seluruh data alternatif pada kriteria ini mempunyai nilai maksimal adalah 15 .

\section{- Desa Kacangan}

Sehingga untuk mendapatkan nilai rating kinerja ternormalisasi adalah sebagai berikut :

$$
\begin{aligned}
r_{i 1 j 1} & =10 / 15 \\
& =0,667
\end{aligned}
$$

\section{- Desa Ngargotirto}

Sehingga untuk mendapatkan nilai rating kinerja ternormalisasi adalah sebagai berikut :

$$
\begin{aligned}
r_{i 1 j 2} & =15 / 15 \\
& =1
\end{aligned}
$$

\section{- Desa Pagak}

Sehingga untuk mendapatkan nilai rating kinerja ternormalisasi adalah sebagai berikut :

$$
r_{i 1 j 3}=10 / 15
$$

- Desa Jati

$$
=0,667
$$

Sehingga untuk mendapatkan nilai rating kinerja ternormalisasi adalah sebagai berikut :

$$
\begin{aligned}
r_{i 1 j 4} & =15 / 15 \\
& =1
\end{aligned}
$$

\section{- Desa Ngargosari}

Sehingga untuk mendapatkan nilai rating kinerja ternormalisasi adalah sebagai berikut :

$$
\begin{aligned}
r_{i 1 j 5} & =15 / 15 \\
& =1
\end{aligned}
$$

b) Kriteria Medan

Kriteria medan menurut pihak Kecamatan Sumberlawang merupakan kriteria yang paling bagus apabila mempunyai nilai yang maksimal (benefit). Dimana diketahui dari seluruh data alternatif pada kriteria ini mempunyai nilai maksimal adalah 60 .

\section{- Desa Kacangan}

Sehingga untuk mendapatkan nilai rating kinerja ternormalisasi adalah sebagai berikut :

$$
\begin{aligned}
r_{21 j 1} & =60 / 60 \\
& =1
\end{aligned}
$$

\section{- Desa Ngargotirto}

Sehingga untuk mendapatkan nilai rating kinerja ternormalisasi adalah sebagai berikut :

$$
\begin{aligned}
\mathrm{r}_{21 \mathrm{j} 2} & =60 / 60 \\
& =1
\end{aligned}
$$

\section{- Desa Pagak}

Sehingga untuk mendapatkan nilai rating kinerja ternormalisasi adalah sebagai berikut :

$$
\begin{aligned}
r_{21 j 3} & =60 / 60 \\
& =1
\end{aligned}
$$

\section{- Desa Jati}

Sehingga untuk mendapatkan nilai rating kinerja ternormalisasi adalah sebagai berikut :

$$
\begin{aligned}
r_{21 j 4} & =40 / 60 \\
& =0,667
\end{aligned}
$$

\section{- Desa Ngargosari}

Sehingga untuk mendapatkan nilai rating kinerja ternormalisasi adalah sebagai berikut :

$$
\begin{aligned}
r_{21 j 5} & =40 / 60 \\
& =0,667
\end{aligned}
$$

c) Kriteria Jarak

Kriteria Jarak menurut pihak Kecamatan Sumberlawang merupakan kriteria yang paling bagus apabila mempunyai nilai yang maksimal 
(benefit). Dimana diketahui dari seluruh data alternatif pada kriteria ini mempunyai nilai maksimal adalah 25.

\section{- Desa Kacangan}

Sehingga untuk mendapatkan nilai rating kinerja ternormalisasi adalah sebagai berikut :

$$
\begin{aligned}
r_{31 j 1} & =20 / 25 \\
& =0,8
\end{aligned}
$$

\section{- Desa Ngargotirto}

Sehingga untuk mendapatkan nilai rating kinerja ternormalisasi adalah sebagai berikut :

$$
\begin{aligned}
r_{31 \mathrm{j} 2} & =20 / 25 \\
& =0,8
\end{aligned}
$$

\section{- Desa Pagak}

Sehingga untuk mendapatkan nilai rating kinerja ternormalisasi adalah sebagai berikut :

$$
\begin{aligned}
r_{31 j 3} & =15 / 25 \\
& =0,6
\end{aligned}
$$

\section{- Desa Jatí}

Sehingga untuk mendapatkan nilai rating kinerja ternormalisasi adalah sebagai berikut :

$$
\begin{aligned}
r_{31 j 4} & =25 / 25 \\
& =1
\end{aligned}
$$

- Desa Ngargosari

Sehingga untuk mendapatkan nilai rating kinerja ternormalisasi adalah sebagai berikut :

$$
\begin{aligned}
r_{31 j 5} & =25 / 25 \\
& =1
\end{aligned}
$$

\section{d) Kriteria Penghasilan}

Penghasilan menurut pihak Kecamatan Sumberlawang merupakan kriteria yang paling bagus apabila mempunyai nilai yang maksimal (benefit). Dimana diketahui dari seluruh data alternatif pada kriteria ini mempunyai nilai maksimal adalah 25.

- Desa Kacangan

Sehingga untuk mendapatkan nilai rating kinerja ternormalisasi adalah sebagai berikut :

$$
\begin{aligned}
r_{41 j 1} & =10 / 25 \\
& =0,4
\end{aligned}
$$

\section{- Desa Ngargotirto}

Sehingga untuk mendapatkan nilai rating kinerja ternormalisasi adalah sebagai berikut :

$$
\begin{aligned}
r_{41 \mathrm{j} 2} & =10 / 25 \\
& =0,4
\end{aligned}
$$

\section{- Desa Pagak}

Sehingga untuk mendapatkan nilai rating kinerja ternormalisasi adalah sebagai berikut :

$$
\begin{aligned}
r_{41 j 3} & =15 / 25 \\
& =0,6
\end{aligned}
$$

\section{- Desa Jati}

Sehingga untuk mendapatkan nilai rating kinerja ternormalisasi adalah sebagai berikut :

$$
\begin{aligned}
r_{41 j 4} & =25 / 25 \\
& =1
\end{aligned}
$$

- Desa Ngargosari

Sehingga untuk mendapatkan nilai rating kinerja ternormalisasi adalah sebagai berikut :

$$
\begin{aligned}
r_{41 j 5} & =10 / 25 \\
& =0,4
\end{aligned}
$$

\section{Analisa Bobot Setiap Kriteria}

Dalam hal ini penulis menggunakan pembobotan dalam setiap kriteria. Adapun bobot setiap kriteria adalah sebagai berikut.

Tabel 1 Bobot Kriteria

\begin{tabular}{|c|c|c|}
\hline Kriteria & Prioritas & Bobot \\
\hline Jumlah Rumah & Sangat Tinggi & 15 \\
\hline Medan & Tinggi & 20 \\
\hline Jarak & Cukup & 25 \\
\hline Penghasilan & Rendah & 30 \\
\hline
\end{tabular}

Tabel diatas akan menentukan besarnya bobot prioritas setiap kriteria. Dimana setiap kriteria mempunyai bobot prioritas yang telah ditentukan berdasarkan hasil penggalian data dari Pihak Kecamatan Sumberlawang.

\section{Nilai Preferensi Setiap Alternatif}

$$
V i=\sum_{j=1}^{n} W j r i j
$$

Keterangan :

$\mathrm{V}_{i} \quad=$ rangking untuk setiap alternatif

$\mathrm{W}_{j} \quad=$ nilai bobot dari setiap kriteria

$\mathrm{r}_{i j}=$ nilai rating kinerja ternormalisasi

a. Desa Ngargosari

$\mathrm{V} 1=(30 \times 1)+(25 \times 0,667)+(20 \times 1)+$ $(15 \times 0,4)=72,675$

b. Desa Pagak

$\mathrm{V} 2=(0,667 \times 30)+(1 \times 25)+(0,6 \times 20)+$ $(0,6 \times 15)=66,01$ 
c. Desa Ngargotirto

$\mathrm{V} 3=(1 \times 30)+(1 \times 25)+(0,8 \times 20)+(0,4 \times 15)$ $=77$

d. Desa Kacangan

$\mathrm{V} 4=(0,667 \times 30)+(1 \times 25)+(0,8 \times 20)+$ $(0,6 \times 15)=70,01$

e. Desa Jati

$\mathrm{V} 5=(1 \times 30)+(0,667 \times 25)+(1 \times 20)+(1 \times 15)$ $=81,675$

\section{Hasil Alternatif Keputusan}

Berdasarkan langkah-langkah perhitungan menggunakan metode Simple Additive Weighting (SAW).

Tabel 2 Hasil Alternatif Keputusan

\begin{tabular}{|c|l|l|}
\hline No & Nama Alternaitf & Poin \\
\hline 1 & Desa Jati & 81,675 \\
\hline 2 & Desa Ngargotirto & 77 \\
\hline 3 & Desa Ngargosari & 72,675 \\
\hline
\end{tabular}

Tabel tersebut merupakan hasil alternatif terhadap pihak Kecamatan Sumberlawang. Dimana hasil alternatif atau rekomendasi calon desa penerima air bersih berdasarkan poin yang paling tinggi dari data poin yang dimiliki oleh alternatif. Berdasarkan hasil tersebut maka diambil 3 dengan nilai yang paling tinggi.

\subsection{Perancangan Sistem}

a. Context Diagram

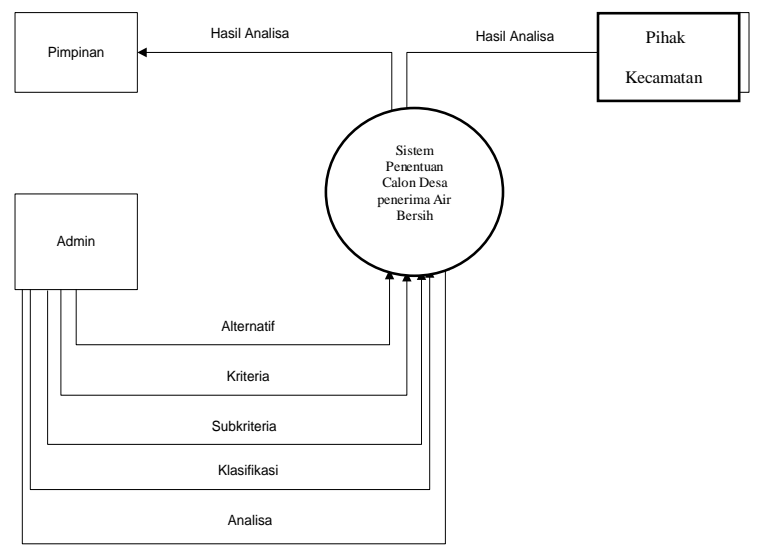

Gambar 1. Context Diagram

Ada 3 pengguna di sistem diantaranya adalah admin, pimpinan dan calon distributor. Admin adalah karyawan dari perusahaan yang mempunyai tugas menjalankan sistem aplikasi Tugas dari admin adalah mengelola data kriteria, data subkriteria, data klasifikasi dan data analisa.
Entitas pimpinan yaitu merupakan orang yang berperan penuh dalam mengambil keputusan terhadap hasil dari aplikasi yang telah dikeluarkan.

b. Data Flow Diagram

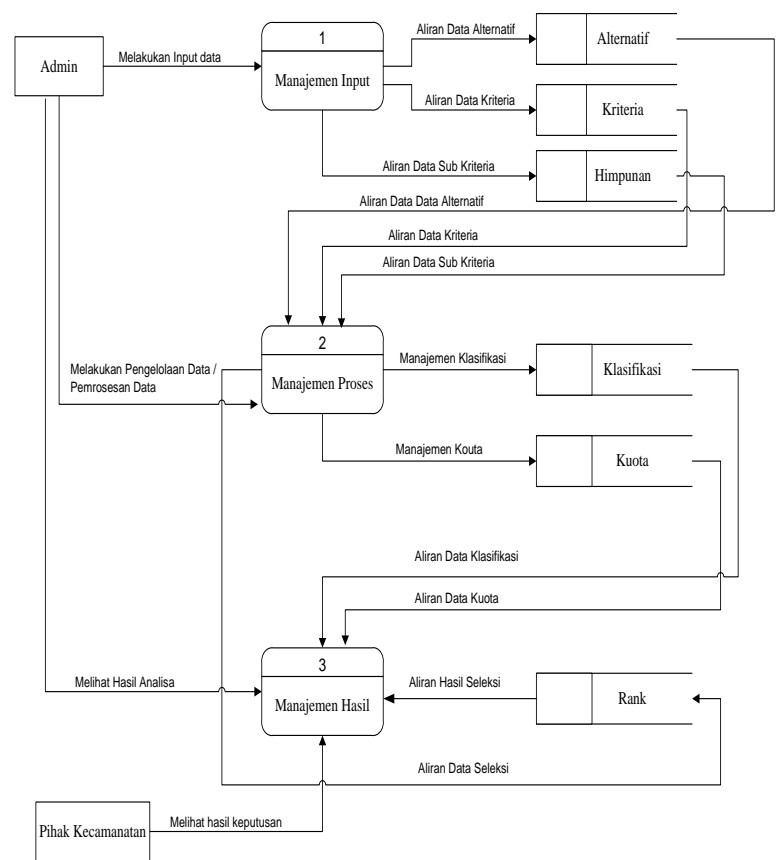

Gambar 2. Data Flow Diagram

Data flow diagram suatu gambaran sistem secara logical, teknik penggambaran alir data dengan menggunakan simbol-simbol tertentu. Terdiri dari 3 proses yaitu input alternatif, kriteria, himpunan, transaski klasifikasi dan kuota serta hasil.

c) Relasłi Antar Tabel

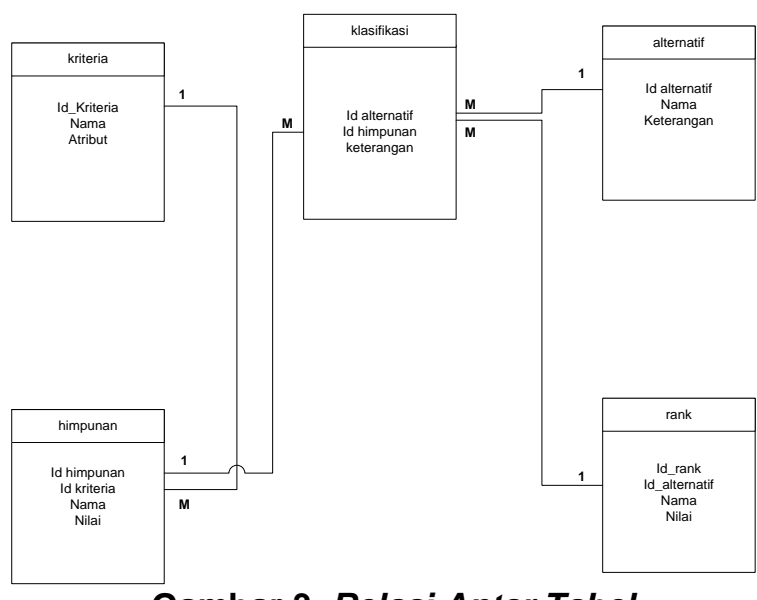

Gambar 3. Relasi Antar Tabel

Relasi antar tabel merupakan suatu hubungan antar tabel yang saling mempunyai keterkaitan. Dalam aplikasi pendukung keputusan yang dibangun oleh Penulis ini, relasi antar tabel mempunyai beberapa tabel 
yang saling berhubungan. Dalam aplikasi ini terdapat 5 buah tabel utama yang mempunyai relasi atau hubungan.

\subsection{Implementasi Aplikasi}

a. Tampilan Halaman Distributor.

Halaman ini berisi data distributor air bersih yang nantinya akan menjadi patner kerjasama. Pada halaman ini berisi no, kode distributor, nama distributor, keterangan dan action. Dan ada juga menu tambah data yang digunakan untuk menambah data distributor air bersih. (Gambar 4)

$$
\text { NOVIANSOFT }
$$
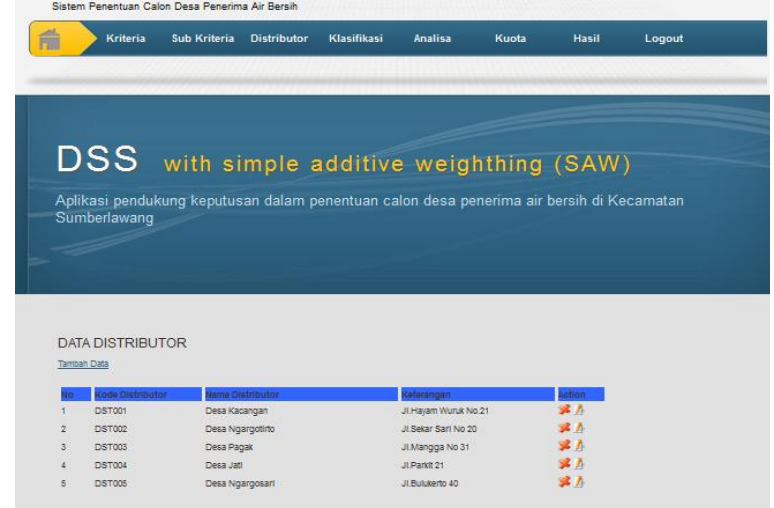

\section{Gambar 4. Tampilan Halaman Distributor}

b. Tampilan Halaman Klasifikasi

Halaman ini digunakan untuk pengklasifiksian dalam penentuan air bersih. Pada halaman ini terdapat no,kode distributor,nama distributor dan keterangan (Gambar 5).

NOVIANSOFT
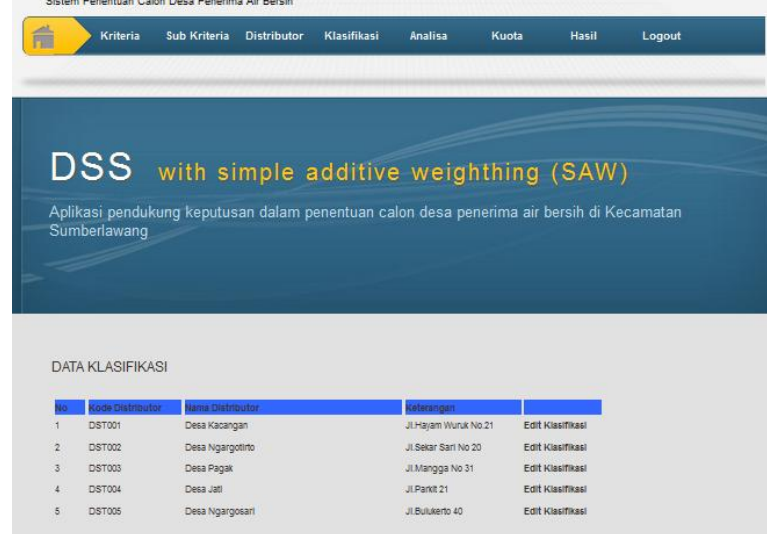

Gambar 5. Tampilan Halaman Klasifikasi

c. Tampilan Halaman Edit Klasifikasi

Halaman ini digunakan melakukan pengubahan terhadap data klasifiaksi atau lebih tepatnya pengelompokan data alternatif beserta data kriteria yang dimiliki oleh setiap alternatif (Gambar 6).

$$
\text { NOVIANSOFT }
$$
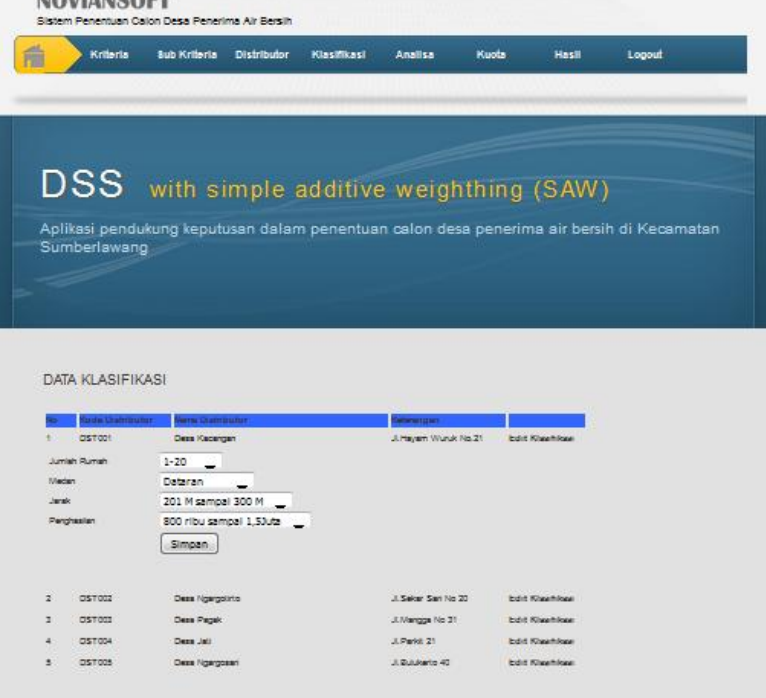

\section{Gambar 6. Tampilan Edit Klasifikasi}

d. Tampilan Halaman Mulai Analisa

Halaman ini digunakan untuk memulai melakukan analisa dari kriteria-kriteria yang telah ditentukan dalam penentuan air bersih. Pada halaman analisa terdapat kriteria yang sudah mempunyai bobot sehingga nantinya pengguna akan memilih bobot pada setiap kriteria (Gambar 7).

\section{NOVIANSOFT}
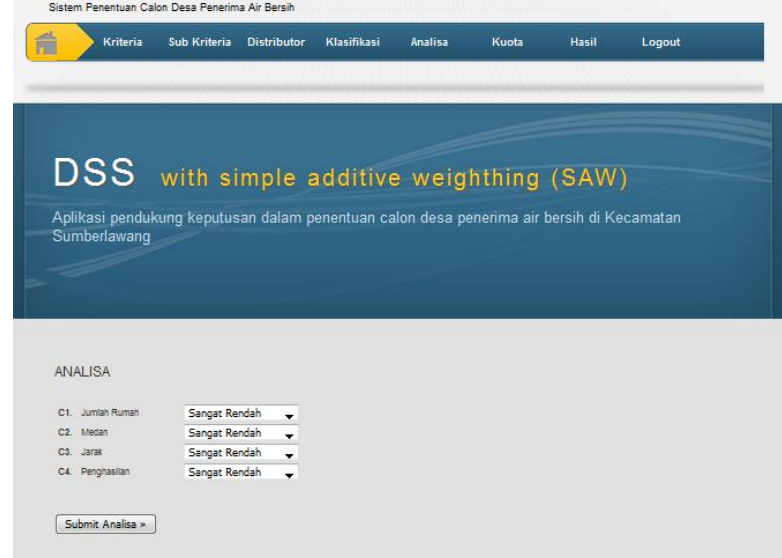

\section{Gambar 7. Tampilan Halaman Analisa}

e. Tampilan Halaman Hasil Alternatif Halaman ini berisi hasil rekomendasi distributor yang cocok untuk menjadi partner dalam pendistribusian air bersih. Pada halaman ini terdapat No, Kuota Distributor, Nama Distributor dan Nilai. 
Pada halaman ini pengguna dalam hal ini admin dapat melihat hasil analisa atau penentuan calon distributor berdasarkan aplikasi yang dibangun. (Gambar 8)

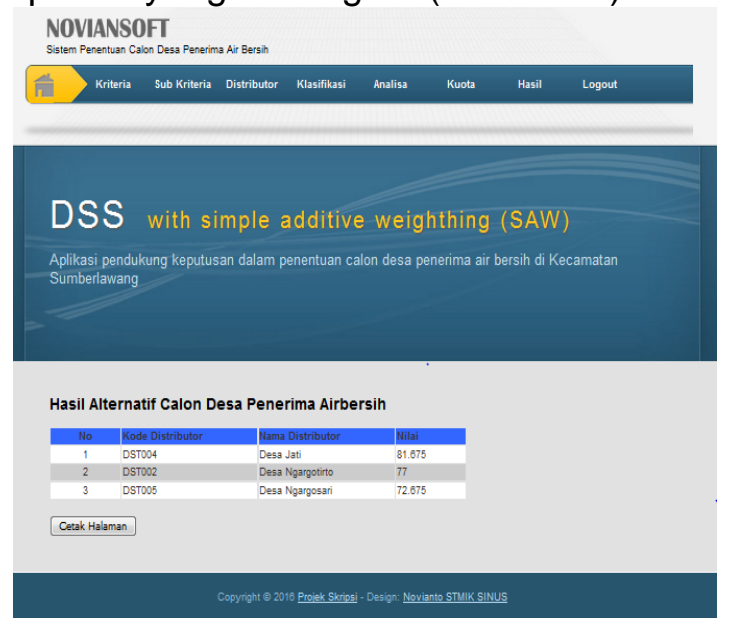

\section{Gambar 8. Tampilan Halaman Hasil}

\subsection{Pengujian}

Metode dalam hal pengujian sistem menggunakan metode Black Box.

Tabel 1. Pengujian Kelas Uji Sistem Login

\begin{tabular}{|l|l|l|l|l|}
\hline $\begin{array}{l}\text { N } \\
0\end{array}$ & $\begin{array}{l}\text { Skenario } \\
\text { Pengujian }\end{array}$ & $\begin{array}{l}\text { Hasil Yang } \\
\text { Diharapkan }\end{array}$ & $\begin{array}{l}\text { Hasil } \\
\text { Pengujian }\end{array}$ & $\begin{array}{l}\text { Kesimp } \\
\text { ulan }\end{array}$ \\
\hline 1 & $\begin{array}{l}\text { Memasukan } \\
\text { Username }\end{array}$ & $\begin{array}{l}\text { Sistem } \\
\text { dapat input } \\
\text { data } \\
\text { username }\end{array}$ & $\begin{array}{l}\text { Sistem } \\
\text { dapat } \\
\text { mengimpu } \\
\text { tkan } \\
\text { username } \\
\text { pengguna }\end{array}$ & Valid \\
\hline 2 & $\begin{array}{l}\text { Memasukan } \\
\text { Password }\end{array}$ & $\begin{array}{l}\text { Sistem } \\
\text { dapat input } \\
\text { data } \\
\text { password }\end{array}$ & $\begin{array}{l}\text { Sistem } \\
\text { dapat } \\
\text { mengimpu } \\
\text { tkan } \\
\text { password } \\
\text { pengguna }\end{array}$ & Valid \\
\hline 3 & Verifikasi & $\begin{array}{l}\text { Sistem } \\
\text { dapat harus } \\
\text { dapat } \\
\text { melakukan } \\
\text { verifikasi } \\
\text { akun } \\
\text { pengguna }\end{array}$ & $\begin{array}{l}\text { Sistem } \\
\text { dapat } \\
\text { melakukan } \\
\text { verifikasi } \\
\text { pengguna }\end{array}$ & Valid \\
\end{tabular}

Tabel 2 Pengujian Kelas Uji Sistem Input Data

\begin{tabular}{|l|l|l|l|l|}
\hline $\begin{array}{l}\text { N } \\
\mathbf{0}\end{array}$ & $\begin{array}{l}\text { Skenario } \\
\text { Pengujian }\end{array}$ & $\begin{array}{l}\text { Hasil Yang } \\
\text { Diharapkan }\end{array}$ & $\begin{array}{l}\text { Hasil } \\
\text { Pengujian }\end{array}$ & $\begin{array}{l}\text { Kesimpul } \\
\text { an }\end{array}$ \\
\hline 1 & $\begin{array}{l}\text { Memasukan } \\
\text { data criteria }\end{array}$ & $\begin{array}{l}\text { Sistem } \\
\text { dapat } \\
\text { melakukan } \\
\text { input data } \\
\text { criteria }\end{array}$ & $\begin{array}{l}\text { Sistem } \\
\text { dapat } \\
\text { memasukan } \\
\text { data criteria }\end{array}$ & Valid \\
\hline 2 & $\begin{array}{l}\text { Melakukan } \\
\text { edit criteria }\end{array}$ & $\begin{array}{l}\text { Sistem } \\
\text { dapat } \\
\text { melakukan } \\
\text { edit data } \\
\text { kriteria }\end{array}$ & $\begin{array}{l}\text { Sistem } \\
\text { dapat } \\
\text { melakukan } \\
\text { edit data } \\
\text { kriteria }\end{array}$ & Valid \\
\hline 3 & $\begin{array}{l}\text { Melakukan } \\
\text { hapus data } \\
\text { criteria }\end{array}$ & $\begin{array}{l}\text { Sistem } \\
\text { dapat } \\
\text { melakukan } \\
\text { hapus data } \\
\text { kriteria }\end{array}$ & $\begin{array}{l}\text { Sistem } \\
\text { dapat } \\
\text { melakukan } \\
\text { hapus data } \\
\text { criteria }\end{array}$ & Valid \\
\hline 4 & $\begin{array}{l}\text { Memasukan } \\
\text { data sub } \\
\text { criteria }\end{array}$ & $\begin{array}{l}\text { Sistem } \\
\text { dapat } \\
\text { melakukan } \\
\text { input data } \\
\text { sub kriteria }\end{array}$ & $\begin{array}{l}\text { Sistem } \\
\text { dapat } \\
\text { memasukan } \\
\text { data sub } \\
\text { criteria }\end{array}$ & Valid \\
\hline
\end{tabular}

\begin{tabular}{|c|c|c|c|c|}
\hline $\begin{array}{l}\mathbf{N} \\
\mathbf{0}\end{array}$ & $\begin{array}{l}\text { Skenario } \\
\text { Pengujian }\end{array}$ & $\begin{array}{l}\text { Hasil Yang } \\
\text { Diharapkan }\end{array}$ & $\begin{array}{l}\text { Hasil } \\
\text { Pengujian }\end{array}$ & $\begin{array}{l}\text { Kesimpul } \\
\text { an }\end{array}$ \\
\hline 5 & \begin{tabular}{l}
\multicolumn{3}{l}{ Melakukan } \\
edit sub \\
criteria
\end{tabular} & $\begin{array}{l}\text { Sistem } \\
\text { dapat } \\
\text { melakukan } \\
\text { edit data } \\
\text { sub kriteria }\end{array}$ & $\begin{array}{l}\text { Sistem } \\
\text { dapat } \\
\text { melakukan } \\
\text { edit data } \\
\text { sub criteria }\end{array}$ & Valid \\
\hline 6 & $\begin{array}{l}\text { Melakukan } \\
\text { hapus data } \\
\text { sub criteria }\end{array}$ & $\begin{array}{l}\text { Sistem } \\
\text { dapat } \\
\text { melakukan } \\
\text { hapus data } \\
\text { sub kriteria }\end{array}$ & $\begin{array}{l}\text { Sistem } \\
\text { dapat } \\
\text { melakukan } \\
\text { hapus data } \\
\text { sub criteria }\end{array}$ & Valid \\
\hline 7 & $\begin{array}{l}\text { Memasukan } \\
\text { data sub } \\
\text { alternative }\end{array}$ & $\begin{array}{l}\text { Sistem } \\
\text { dapat } \\
\text { melakukan } \\
\text { input data } \\
\text { sub } \\
\text { alternatif }\end{array}$ & $\begin{array}{l}\text { Sistem } \\
\text { dapat } \\
\text { memasukan } \\
\text { data sub } \\
\text { alternative }\end{array}$ & Valid \\
\hline 8 & $\begin{array}{l}\text { Melakukan } \\
\text { edit sub } \\
\text { alternative }\end{array}$ & $\begin{array}{l}\text { Sistem } \\
\text { dapat } \\
\text { melakukan } \\
\text { edit data } \\
\text { sub } \\
\text { alternatif }\end{array}$ & $\begin{array}{l}\text { Sistem } \\
\text { dapat } \\
\text { melakukan } \\
\text { edit data } \\
\text { sub } \\
\text { alternative }\end{array}$ & Valid \\
\hline 9 & $\begin{array}{l}\text { Melakukan } \\
\text { hapus data } \\
\text { sub } \\
\text { alternative }\end{array}$ & $\begin{array}{l}\text { Sistem } \\
\text { dapat } \\
\text { melakukan } \\
\text { hapus data } \\
\text { sub } \\
\text { alternatif }\end{array}$ & $\begin{array}{l}\text { Sistem } \\
\text { dapat } \\
\text { melakukan } \\
\text { hapus data } \\
\text { sub } \\
\text { alternative }\end{array}$ & Valid \\
\hline $\begin{array}{l}1 \\
0\end{array}$ & $\begin{array}{l}\text { Melakukan } \\
\text { validasi data } \\
\text { sub } \\
\text { alternative }\end{array}$ & $\begin{array}{l}\text { Sistem } \\
\text { dapat } \\
\text { melakukan } \\
\text { validasi } \\
\text { data sub } \\
\text { alternatif }\end{array}$ & $\begin{array}{l}\text { Sistem } \\
\text { dapat } \\
\text { Melakukan } \\
\text { validasi } \\
\text { data sub } \\
\text { alternative }\end{array}$ & Valid \\
\hline
\end{tabular}

Tabel 3 Pengujian Kelas Uji Sistem Proses Data

\begin{tabular}{|c|c|c|c|c|}
\hline $\begin{array}{l}\mathrm{N} \\
\mathrm{O}\end{array}$ & $\begin{array}{l}\text { Skenario } \\
\text { Pengujian }\end{array}$ & $\begin{array}{l}\text { Hasil Yang } \\
\text { Diharapkan }\end{array}$ & $\begin{array}{l}\text { Hasil } \\
\text { Pengujian }\end{array}$ & $\begin{array}{l}\text { Kesimpul } \\
\text { an }\end{array}$ \\
\hline 1 & $\begin{array}{l}\text { Melakukan } \\
\text { pengelompo } \\
\text { kan data }\end{array}$ & $\begin{array}{l}\text { Sistem } \\
\text { dapat } \\
\text { melakukan } \\
\text { pengelompo } \\
\text { kan atau } \\
\text { pengisian } \\
\text { data kriteria } \\
\text { pada setiap } \\
\text { alternatif }\end{array}$ & $\begin{array}{l}\text { Sistem } \\
\text { dapat } \\
\text { melakukan } \\
\text { pengelompo } \\
\text { kan atau } \\
\text { pengisian } \\
\text { data kriteria } \\
\text { pada setiap } \\
\text { alternative }\end{array}$ & Valid \\
\hline 2 & $\begin{array}{l}\text { Cek Validasi } \\
\text { data }\end{array}$ & $\begin{array}{l}\text { Sistem } \\
\text { dapat } \\
\text { melakukan } \\
\text { pengecekan } \\
\text { data yang } \\
\text { rangkap } \\
\text { dan valid }\end{array}$ & $\begin{array}{l}\text { Sistem } \\
\text { dapat } \\
\text { melakukan } \\
\text { pengecekan } \\
\text { data yang } \\
\text { rangkap } \\
\text { dan valid }\end{array}$ & Valid \\
\hline 3 & $\begin{array}{l}\text { Melakukan } \\
\text { pembobotan } \\
\text { criteria }\end{array}$ & $\begin{array}{l}\text { Sistem } \\
\text { dapat } \\
\text { melakukan } \\
\text { pembobota } \\
\mathrm{n} \text { kriteria }\end{array}$ & $\begin{array}{l}\text { Sistem } \\
\text { dapat } \\
\text { melakukan } \\
\text { pembobota } \\
\text { n criteria }\end{array}$ & Valid \\
\hline 4 & $\begin{array}{l}\text { Perhitungan } \\
\text { menggunaka } \\
\text { n SAW }\end{array}$ & $\begin{array}{l}\text { Sistem } \\
\text { dapat } \\
\text { melakukan } \\
\text { proses } \\
\text { perhitungan } \\
\text { dengan } \\
\text { Metode } \\
\text { SAW }\end{array}$ & $\begin{array}{l}\text { Sistem } \\
\text { dapat } \\
\text { melakukan } \\
\text { proses } \\
\text { perhitungan } \\
\text { dengan } \\
\text { Metode } \\
\text { SAW }\end{array}$ & Valid \\
\hline 5 & $\begin{array}{l}\text { Sistem } \\
\text { Manajemen } \\
\text { Kuota }\end{array}$ & $\begin{array}{l}\text { Sistem } \\
\text { Dapat } \\
\text { melakukan } \\
\text { manajemen } \\
\text { pembatasan } \\
\text { Calon } \\
\text { Distributor }\end{array}$ & $\begin{array}{l}\text { Sistem } \\
\text { Dapat } \\
\text { melakukan } \\
\text { manajemen } \\
\text { pembatasan } \\
\text { Calon } \\
\text { Distributor }\end{array}$ & Valid \\
\hline
\end{tabular}

\section{Penutup}

5.1. Kesimpulan

1. Sistem Pendukung Keputusan Dalam Menentukan Calon desa penerima Air Bersih di Kecamatan Sumberlawang 
yang dibuat oleh penulis sudah sesuai dengan proses analisa dengan metode Simple Additive Weighted. Hal tersebut dibuktikan dengan hasil proses perhitungan pembobotan sampai dengan memperoleh nilai pada setiap alternatif. dimana hasil sistem sama dengan proses analisa perhitungan secara manual.

2. Sistem pendukung keputusan yang telah dibuat oleh Penulis, dengan menggunakan jumlah skenario pengujian sebanyak 22 , hasil nilai valid sebanyak 22 dan hasil nilai tidak valid 0 .

3. Hasil perhitungan menggunakan metode Simple Additive Weighted pada kasus penentuan calon desa penerima air bersih di Kecamatan sumberlawang. Menghasilkan data calon distributor yang paling tinggi adalah Desa Jati dengan nilai poin sebesar 81,67 dan diperingkat kedua yaitu Desa Ngargotirto dengan nilai sebesar 77 .

\subsection{Saran}

Secara umum aplikasi pendukung keputusan yang dibuat sudah mampu memberikan alternatif keputusan bagi pihak kecamatan sumberlawang dalam membantu penentuan calon desa penerima air bersih. Akan tetapi sistem yang bangun oleh penulis perlu dikembangkan sistem komunikasinya dengan mengguna web service yang telah disediakan oleh pengembang aplikasi web. Sehingga nantinya aplikasi pendukung keputusan yang telah dibuat oleh penulis dapat melakukan sinkronisasi dengan sistem aplikasi lainya yang masih terkait dengan sistem maupun informasi yang sama.

\section{DAFTAR PUSTAKA}

[1] J. G. Brookhear, Computer Science: an Overview,. Jakarta: Erlangga, 2010.

[2] Y.-J. Wang, "A fuzzy multi-criteria decision-making model based on simple additive weighting method and relative preference relation," Appl. Soft Comput., vol. 30, pp. 412-420, May 2015.

[3] H. Shakouri G., M. Nabaee, and S. Aliakbarisani, "A quantitative discussion on the assessment of power supply technologies: DEA (Data Envelopment Analysis) and SAW (simple additive weighting) as complementary methods for the "Grammar,"' Energy, vol. 64, pp. 640-647, Jan. 2014.

[4] J. Tamošaitienè, E. K. Zavadskas, and Z.
Turskis, "Multi-criteria Risk Assessment of a Construction Project," Procedia Comput. Sci., vol. 17, pp. 129-133, Jan. 2013.

[5] M. Jaberidoost et al., "Pharmaceutical supply chain risk assessment in Iran using analytic hierarchy process (AHP) and simple additive weighting (SAW) methods," J. Pharm. Policy Pract., vol. 8, no. 1, pp. 1-10, Feb. 2015.

[6] I. Kaliszewski and D. Podkopaev, "Simple additive weighting-A metamodel for multiple criteria decision analysis methods," Expert Syst. Appl., vol. 54, pp. 155-161, Jul. 2016.

[7] Fathansyah, Basis Data. Bandung: Informatika, 2010.

[8] Y.-S. Huang, W.-C. Chang, W.-H. Li, and Z.-L. Lin, "Aggregation of utility-based individual preferences for group decisionmaking," Eur. J. Oper. Res., vol. 229, no. 2, pp. 462-469, Sep. 2013.

[9] Z.-P. Fan, X. Zhang, F.-D. Chen, and Y. Liu, "Multiple attribute decision making considering aspiration-levels: A method based on prospect theory," Comput. Ind. Eng., vol. 65, no. 2, pp. 341-350, Jun. 2013.

[10] S. Kusumadewi, Aplikasi Logika Fuzzy Untuk Pendukung Keputusan. Yogyakarta: Graha IImu, 2010. 